\title{
A késő rézkori fémművesség emlékei a Kis-Balaton területén és tágabb térségében
}

\author{
BONDÁR MÁRIA \\ MTA BTK Régészeti Intézet, 1014 Budapest, Úri u. 49., \\ e-mail: bondar.maria@btk.mta.hu
}

\begin{abstract}
BONDÁR, M.: The Late Copper Age relics of metalwork in the Little Balaton and surrounding area.

Abstract: This paper collects the relics of metalwork in the Little Balaton and surrounding area, with the probably most outstanding find of the Late Copper Age metalworking. The article covers the Vörs diadem and its problematics and possible resolutions (e.g. the sex of skeleton, the raw material of diadem and the localisation of the site).
\end{abstract}

Keywords: Late Copper Age, Baden complex, Metalwork, jewellery, diadem of Vörs, society

\section{A vizsgált terület kutatási helyzete}

A Kis-Balaton és a Balaton déli partvidéke évtizedek óta a jól kutatott területek közé tartozik. A Balaton délnyugati csücskéhez csatlakozó terület, a Fenékpuszta és Balatonhídvég közötti térség a XVIII. század végéig mocsaras vízterület, a tó természetes vízszürője volt. A XIX. század végén a Balaton déli partján futó vasútvonal és a Sió-zsilip megépítése jelentős ökológiai változásokat eredményezett a vízháztartásban. A Kis-Balaton mocsaras térsége elveszítette vízszürő funkcióját, a Zala hordaléka közvetlenül a Keszthelyi-öbölben rakódott le és a mezőgazdasági termeléssel összefüggő kémiai szennyezéseket sem tudta csökkenteni a Balaton „elöszobája”. Mindennek következtében a huszadik század hetvenes éveinek elején ökológiai katasztrófa fenyegette a Balaton vízrendszerét. Az eredeti állapotok helyreálításához a Nyugat-Dunántúli Környezetvédelmi és Vízügyi Igazgatóság kidolgozta a „Kis-Balaton Vízvédelmi Rendszer" programját, amely két ütemben valósulhatott meg. Elsőként a Hídvégi-tározó 1870 hektárnyi területe készült el, amelyet 1985-ben elárasztottak. A II. ütem a Fenéki-tó 5000 hektáros területének elárasztása, a 2000-es évek közepén valósult meg.

Ezt a komoly természetvédelmi rekonstrukciós munkát terepbejárások és nagyléptékű régészeti leletmentések is megelőzték, ennek köszönhetően minden korszakból jelentős lelőhelyek láttak napvilágot. Az I. ütem építése előtti régészeti munkákat a Somogy Megyei Múzeumok Igazgatósága, a Zala Megyei Múzeumok Igazgatósága, a Magyar Nemzeti Múzeum és az MTA Régészeti Intézetének munkatársai végezték. ${ }^{1}$ A II. ütem régészeti feltárásait a Zala Megyei Múzeumok Igazgatósága, elsősorban a keszthelyi Balaton Múzeum régészei valósították meg.

\footnotetext{
1 KÖLTŐ-VÁNDOR 1996.
}

A kilencvenes évektől szisztematikus terepbejárások derítették fel a tervezett M7 autópálya nyomvonalát, ${ }^{2}$ majd a fontosabb csomópontokon, agyagnyerő helyeken régészeti feltárásokat is végezhettek a területileg illetékes múzeumi szakemberek és az MTA Régészeti Intézetének munkatársai. ${ }^{3}$ A Kis-Balaton környékét is érintő projektben nagy területek feltárása során új lelőhelyeket és nagymennyiségủ leletanyagot találtak a régészek szinte minden korszakból.

\section{A késő rézkori fémművességről}

A késő rézkori fémtárgyak - bár kerültek elő újabb, jelentős darabok - nem gyarapodtak olyan mértékben, mint ahogy az remélhető lett volna e nagyléptékű terepmunkáktól. A korábbi időszak tömör, sok fémet tartalmazó, öntött rézcsákányainak tömegéhez és aranytárgyainak számához viszonyítva a késő rézkori fémtárgyak mennyisége minimális mind a hazai, mind a környezö országok területén. A jelenség okát nem ismerjük.

A kutatók általános véleménye szerint ez két módon magyarázható: vagy megváltozott a késő rézkori közösségek szemlélete a fémeket illetően (nem tartották fontosnak, értékhordozónak), vagy kimerültek a korábbi nyersanyag lelőhelyek.

Természetesen mindkét magyarázat elképzelhető. A kérdés eldöntéséhez a fémfeldolgozás technológiájának ismerete és a nyersanyagforrások felderítése vihetne közelebb, de jelenleg még ez sem megoldott. Nem ismerjük a középső rézkori fémfeldolgozás pontos technológiáját. Nem ismerjük a rézcsákányok öntőformáit, az aranycsüngők és korongok öntési/kalapálási módját. A rézkorban létesített bányát csak néhány helyről ismerünk (Aibunár, Rudna Glava, Majdanpek, Brixlegg). Szokták még említeni a Mecseket és Recsk térségét a Mátrában is a rézérc lelőhelyek (azurit, malachit) között, de nincs tudomásom olyan analízisről, amely vizsgálta volna pl. a Kárpát-medencében előkerült réztárgyak és az említett - minden bizonnyal nem a rézkor óta használt - magyarországi hegységek nyersanyaga közötti kapcsolatot.

2 BONDÁR-HONTI-KISS 2000, 93-97, 1, 2a, 2b táblázat

3 BONDÁR-HONTI-KIss 2000, HoNTI et al. 2002, HoNTI et al. 2004 (ez a három beszámoló önálló kötetként is megjelent a Somogy Megyei Múzeumok Igazgatósága és az MTA Régészeti Intézete közös kiadványaként, a Nemzeti Autópálya Zrt támogatásáva 2004-ben (KIRÁLY (szerk.) 2004), HONTI et al. 2006, BELÉNYESYHONTI-KIss (szerk.) 2007 
Csak az utóbbi néhány évben vált hangsúlyosabbá a készítési folyamat egyes kérdéseinek elemzése a régészetben is alkalmazható, új műszeres vizsgálatokkal és a kísérleti régészet alkalmazásával. $E$ megélénkült metallurgiai kutatásokban a fémanalízisek még nem tartanak ott, hogy a tárgyak valószínűsíthető származási helyét, geológiai környezetét az elemösszetétel, bizonyos speciális komponensek alapján meg tudják határozni. Ehhez elengedhetetlenül szükséges lenne a bányák helyének ismerete, és az onnan származó nyersanyag összetételének összehasonlítása a régészeti leletekkel. A korabeli bányákban előforduló nyersanyag és a Kárpát-medencei réztárgyak komponenseinek összehasonlítása még nem történt meg, így innen közelítve sem tudjuk megválaszolni, miért változott meg a fémmüvesség szerepe a késő rézkori közösségek életében. Valóban kimerültek a nyersanyagforrások?

A késő rézkori fémszegénységre magyarázat lehet az a tény is, hogy a korábbiaktól eltérő technológiájú, gyengébb minőséget produkáló fémfeldolgozást kell feltételeznünk, amelynek termékeiből csak nagyon kevés maradt meg. Tudjuk, hogy nem feltétlenül kellett bányászni a rézérceket, a termésréz a felszínen is sok helyen (nem túl nagy mennyiségben) előfordul. A rögökből - amint ezt számos dokumentált kísérlet is bizonyítja - nagyon könnyen, viszonylag alacsony hőfokon, primitív tábortűz mellett is kinyerhető a fém, amely azután már könnyen alakítható, kalapálható hidegen is (fa vagy kőeszközzel). Ez utóbbi technológia megmagyarázná, miért van kevés és gyenge minőségű réztárgy a késő rézkorból és a vándorló fémművesek feltételezett működése is érthetővé válna. Ök magukkal vihették a rögöket, bárhol kiolvaszthatták belöle a szükséges fémet, elkészítették az egyszeri használatnak megfelelő öntőformát és öntőtégelyt agyagból, s kiöntötték a szükséges tárgyat vagy a rézszalagot, amit hidegen kalapáltak az igényeknek megfelelően. Nem kellett mühely, nem kellett nagy felszerelés ehhez az egyszerű folyamathoz.

Nehéz meghatározni azt a szellemi, gazdasági hátteret, amelyből megtudhatnánk, hogy milyen jelentőséget tulajdoníthattak a Kr. e. 3600/3500-3000/2800 közötti évszázadokban a réznek és az aranynak. Nyilvánvalóan nem felejthették el az öntés technológiáját, a fémmegmunkálás különböző módozatait. Ha ugyanolyan fontos lett volna a közösség életében ez a két fém, mint a középső rézkorban, akkor felkutattak volna fémlelőhelyeket vagy kereskedelmi kapcsolatokat, amelyek biztosították volna az alapanyagot. Ha tényleg kimerültek volna az érclelőhelyek, akkor más anyaggal helyettesíthették volna a csillogó aranyat és a komoly fegyvernek tekinthető rézcsákányt. De a leletek tanúsága szerint nem ez történt. A késő rézkori közösségek életében nem játszott szerepet a nehéz csákány sem fegyverként sem munkaeszközként és az aranycsüngők sem találhatók meg a lelőhelyeken. Minden jel arra mutat, hogy ebben az időszakban a réz és az arany a gazdasági és társadalmi paradigma váltás áldozata lett, korábbi jelentőségük valamilyen okból megváltozott.
A badeni komplexum magyarországi leletanyagából mindössze 25 lelőhelyről közöltek vagy említenek réztárgyakat. Egyszerü ékszerekről (rézhuzalból nyújtott, kalapált hengeres gyöngyökről, gyürüről illetve huzalkarikáról), ruhadíszről (gombok), alapanyagról (rézhuzal, rézlemez) vagy különböző szerszámokról (ár, kés, tü, tőr, balta) tudunk. ${ }^{4}$ Komolyabb ékszert 3 lelőhelyröl ismerünk: egy rézdiadémot, ${ }^{5}$ egy réznyakperecet, ${ }^{6}$ és egy rézkarperecet. ${ }^{7}$ Két lelőhelyen öntőtégelyek töredékeit, két helyen rézbalta öntőmintáját találták meg. ${ }^{8}$

\section{A késő rézkori metallurgia emlékei a térségből}

A késő rézkor általános fémszegénységével szemben a Kis-Balaton és a tó déli partvidéke meglepően „gazdagnak" tűnik: a magyarországi összes lelőhely kicsivel több, mint egyharmada, hét lelőhely van ebben a térségben (1. ábra).

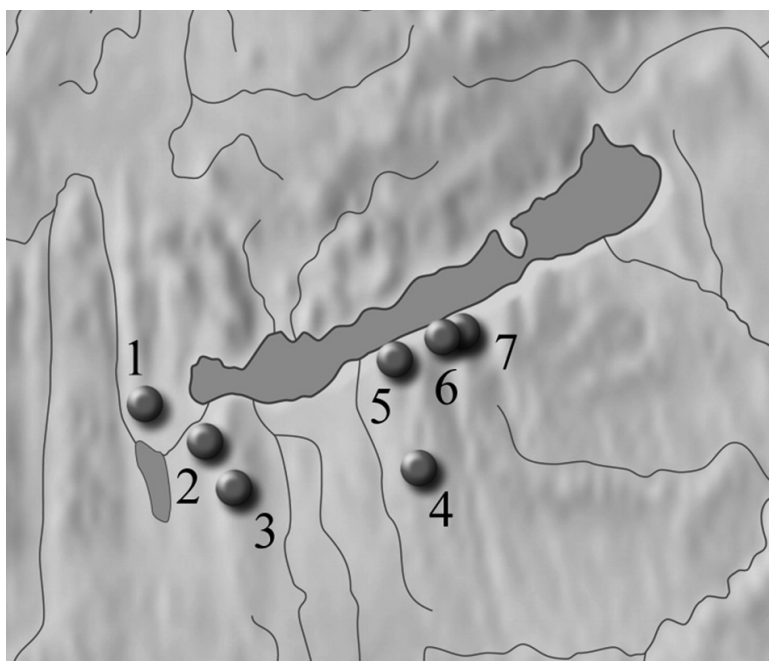

1. ábra. $A$ késő rézkori fémtárgyak a térségben:

Balatonboglár-Zrínyi u. (5), Balatonlelle-Felső

Gamász (6), Balatonlelle-Rádpuszta (7), LengyeltótiRicepuszta (4), Sármellék-Égenföld (1) Tikos-Nyárfás dülő (3), Vörs-Majorsági épületek (2) (a térképet készítette: Ősi Sándor)

4 VIRÁG 1999, 5-6. jegyzet, BondÁR 2015b

5 Vörs-Majorsági épületek (BANNER 1956, Taf. LXXXVII.)

6 Szebény-Farkasluk dúlő (Baranya m.) Ligner Jácint ásatása, sajnos a tárgy elveszett (LIGNER 2010, 353).

7 Balatonlelle-Rádpuszta (67/5. Ih.) Molnár István - Sípos Carmen ásatása (MoLNÁR-Sípos 2005, 180, MolNÁR-SíPos 2006, 52, XVIII. tábla 1. sírfotó)

8 három öntőtégely töredékei: Lánycsók (ECSEDY 1977, Taf. XI. 3-5, Taf. XII. 1-3), egy tégelytöredék: Zók-Várhegy: EcSEDY 1990, Fig. 7), az anyagvizsgálatukat Id. ECSEDY 1990, Chart 1-2; rézbalta öntőmintája: Budapest-Andor u. (ENDRŐDI 1997, 46. kép 4) rézbalta agyag öntőmintájának fele: Budapest-Kőérberek, Tóváros Lakópark (TEREI et al. 2004, 196). Egy homokkőből készült, középen félgömb alakban kimélyített öntőforma(?) ketté tört töredékét említi még Kántorjánosi 23/26. objektumból György László (GYÖRGY 2012, 104, 28. t. 1). A hivatkozott tábla képaláírásában a tárgy örlőkőként szerepel. Ha valóban öntőminta volt (ami a szerző szerint még a használat előtt eltört), sajnos, nem tudjuk, milyen típusú tárgy öntésére szolgálhatott. 
Vörs-Majorsági épületek lelőhelyen 1952-ben csontvázas sírból rézdiadém, ${ }^{9}$ Balatonboglár-Zrínyi utcai tömegsírból 1980-ban három réz gyöngy töredéke, ${ }^{10}$ Sármellék-Égenföld települési gödréből 1985ben réztőr és rézkés, ${ }^{11}$ Balatonlelle-Felső Gamászon 2002-ben feltárt csontvázas sírokból rézgyöngyök, réztű, rézvéső, réztőr, ${ }^{12}$ Tikos-Nyárfás dűlő települési gödréből 2003-ban rézkés, ${ }^{13}$ Balatonlelle-Rádpusztán 2005-ben feltárt csontvázas sírból rézkarperec ${ }^{14}$ és Lengyeltóti-Ricepuszta egyik települési gödréből 2009-ben rézkés ${ }^{15}$ került elő. A kalapált, tekercselt rézgyöngyök kivételével a tárgyak viszonylag jó minőségű, jelentős darabok a késő rézkor egész fémmüvességi leltárában.

A badeni komplexum teljes elterjedési területén mindmáig egyedülálló lelet, a vörsi diadém (2. ábra). Sajnos, ez a párhuzam nélküli fejdísz az elmúlt évtizedekben fokozatosan kikerült a szakirodalom látóköréből, annak ellenére, hogy a fémművesség napjainkban az egyik leghangsúlyosabb kutatási terület.

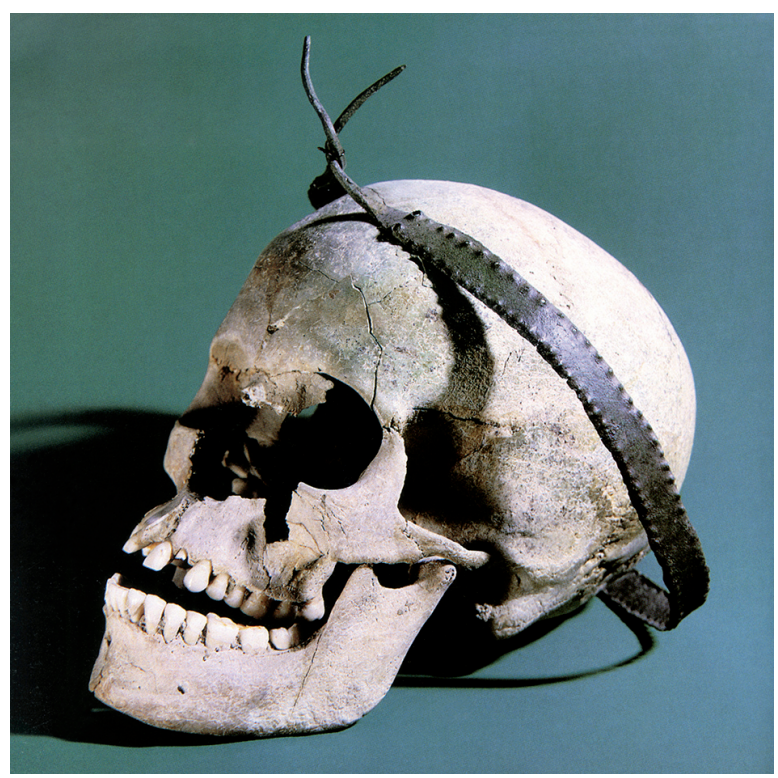

2. ábra. A vörsi koponya a diadémmal (fotó: Kádas Tibor)

9 BANNER 1956, Taf. LXXXVII.

10 HONTI 1981, 4. kép 11. e-g Honti Szilvia spirálcsövecskének írja le a tárgyakat. Valójában ezek rézlemezből csavart henger alakú gyöngyök (VIRÁG 1999, 5. jegyzet). A kalapált rézlemezböl készült gyöngyök készítés technikáját a budakalászi temetö feldolgozásnál tanulmányozhattam. A 113. sírban a hosszúkás dentalium kagylóra tekercselték fel a rézlemezt (BONDÁR 2009, 293).

11 VIRÁG 1999, 2. kép

12 gyöngyök töredékei: NAGY 2010, 412-413, Abb. 22. 7, Abb. 24 19, Abb. 36. 6, Abb. 42. 21-23, réztű: NAGY 2010, Abb. 24. 13, rézvéső: Abb. 24. 15, Abb. 44. 16, réztőr: NAGY 2010, Abb. 11. 8.

13 HoNTI et al. 2004, 47.

14 MolnÁR-Sípos 2005, 180, MolnÁR-Sípos 2006, 52

15 NÉMETH 2009, 261

\section{A vörsi diadémos sírral és lelettel kapcsolatos problémák}

Mint minden unikális lelet, így a vörsi diadém is számos probléma forrása: a pontos lelőhely, a csontváz antropológiai meghatározása, a lelet értelmezése, analógiái, keltezési problémái, a diadém anyagának kérdése. A vörsi diadém körüli ellentmondásos megállapításokkal szembesülve igyekeztem a problémákat tisztázni visszanyúlva az ősforrásig, az eredeti ásatási dokumentációig ${ }^{16}$ és összeszedve minden korábbi tényt, vizsgálati adatot minderről. Mindezek miatt szükségesnek tartottam újraközlését és a sírral és lelettel kapcsolatos problémák áttekintését új szempontok szerint, modern vizsgálati módszerekkel kiegészítve mindazt, amit jelenleg tudhatunk e különleges tárgyról. ${ }^{17}$ Vegyük sorra röviden a fontosabb problémákat.

\section{A lelöhely lokalizálása}

A fejdísz egy csontvázas sírban volt a halott fején. A sírt a keszthelyi múzeum fiatal segédmuzeológusa, Pekáry Tamás tárta fel leletmentésként. Az első jelentés az Archaeologiai Értesítőben jelent meg erről. Eszerint: „... A falu ÉK-i szélén, az ún. majorsági épületektöl mintegy 100 m-re, ÉK-re három silógödröt ástak. A gödrökből 3 csontvázas sír került elö...." 18 A különleges lelőhelyet Banner János még az utolsó pillanatokban be tudta illeszteni akkor lezárt monográfiájának a végére (324. Ih.). ${ }^{19}$ Banner néhány további információval egészítette ki az első híradást. Az előkerült sírok közül az első La Tène kori volt, kettő a péceli kultúrába tartozott. Banner - bár minden bizonnyal ismerte Pekáry ásatási dokumentációját - a lelőhely pontos helyével nem foglalkozott, Vörs-Majorsági épületek néven került be a szakirodalomba.

A lelöhely látszólag rendben van, több katalógus térképén szerepel is. Pekáry Tamás dokumentációját kézbe véve, s helyszínrajzát a modern térképekkel összevetve viszont arra a megállapításra jutottam, hogy a találási hely nem lehet azonos a mai „Vörsi major" nevű hellyel. Pekáry Tamás helyszíni leírását olvasva ugyanis az derült ki, hogy vagy az égtájakat tévesztette el, vagy a szakirodalomban szerepel tévesen a lelőhely a közölt térképeken. Hosszas levelezés és nyomozás után azt tapasztalhattam, hogy Pekáry - bár nem volt nála sem tájoló, sem mérőszalag - jól írta le a lelőhelyet. A lokalizálást Tóth Dénes tanár úr, helytörténész (Vörs) és Költő László segítségével tudtam helyesbíteni, az elökerülés után több mint 60 évvel sikerült a diadémos sír helyét térképen is helye-

16 Ezúton is szeretnék köszönetet mondani P. Barna Juditnak, Havasi Bálintnak a vörsi koponya és diadém kölcsönzési lehetőségért és vizsgálatainak engedélyezéséért.

17 BONDÁR 2015, BONDÁR 2015a, BONDÁR 2015b

18 PEKÁRY 1954, 72.

19 BANNER 1956, 111. Taf. LXXXVII. A kötetben már szerepelt egy vörsi lelöhely, Vörs-Belterület 42. sorszámmal (BANNER 1956, 3334, a két lelöhely nem azonos. Ez utóbbiról bővebben: BONDÁR $2015 b$. 


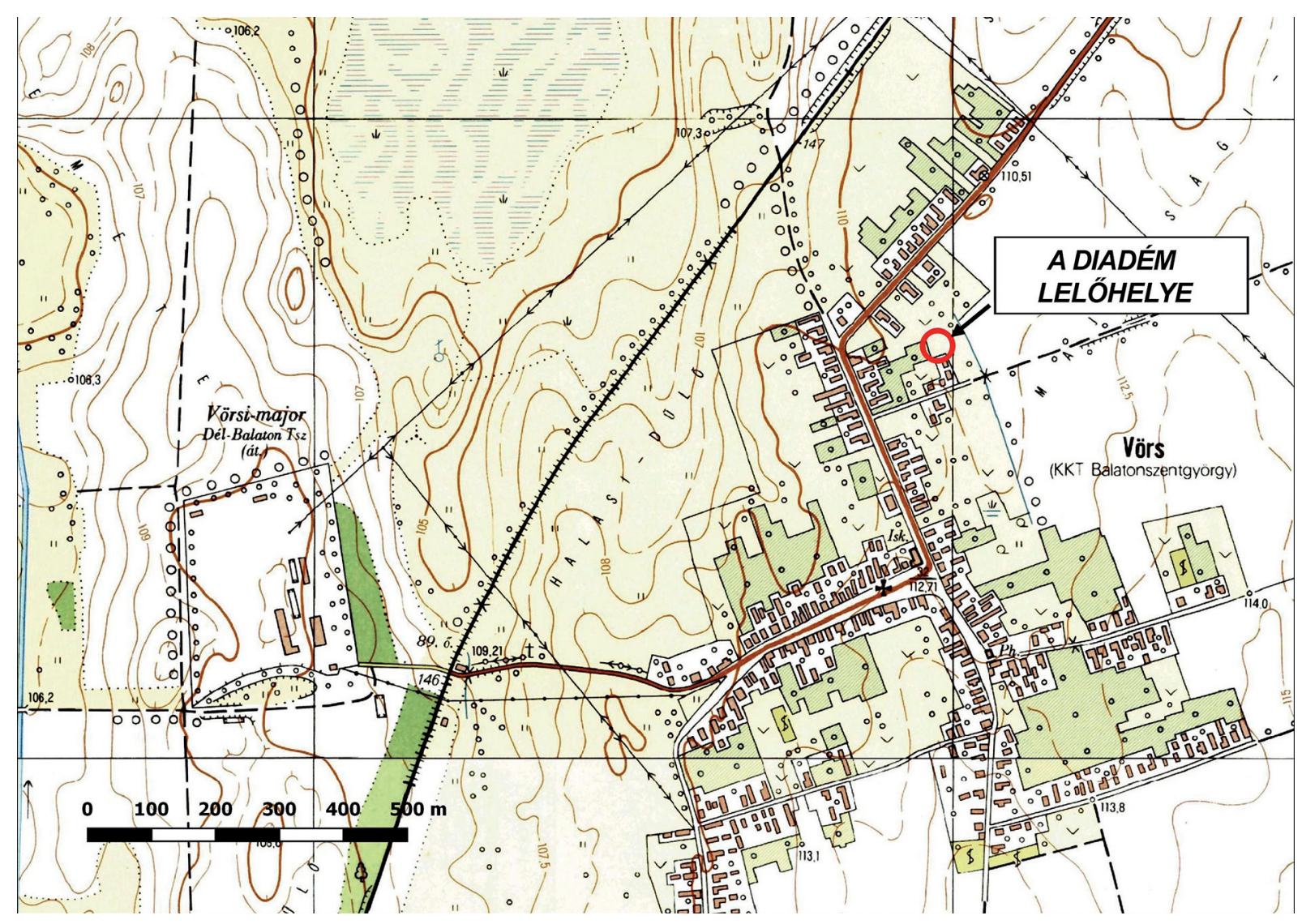

3. ábra. A diadémos sír lelöhelye

(a térképet készitette: Vágvölgyi Bence, Ősi Sándor)

sen rögzítenünk. ${ }^{20} \mathrm{~A}$ különleges leletet is megőrző sír valójában a ma is álló, egykori Festetics kastély majorságának területén került elő (3. ábra). ${ }^{21}$

\section{Antropológiai kérdések}

A Banner monográfiában szerepelő nagyobb temetők anyagát Nemeskéri János határozta meg, és dolgozta fel, Vörsről egy sírt említ, ${ }^{22}$ amelyről csak feltételezhetö, hogy a diadémos sír csontváza. Banner János nem foglakozott a vörsi csontok embertani adataival, monográfiájában semmilyen utalás nincs a csontváz vizsgálatára, vagy őrzési helyére. Zoffmann Zsuzsanna a kárpát-medencei rézkori népességről szóló kandidátusi disszertációjában sem találtam információt a csontváz hollétéröl, szakszerü elemzéséről. ${ }^{23}$

20 Ezúton is köszönöm Honti Szilvia, Költő László és Tóth Dénes szíves segítségét. A térinformatikai térképet Vágvölgyi Bence készítette el, amelyet ezúton is köszönök.

21 BONDÁR 2015a

22 NEMESKÉRI 1956, 298: „Die Zahl der zur Péceler Kultur gehörigen und archäologisch datierten anthropologischen Funde beträgt 162, sie gelangten von folgenden Fundorten in die Anthropologische Sammlung des Naturwissenschaftilichen Museums des Ungarischen Nationalmuseums: Alsónémedi (Kom. Pest - 43 Funde), Budakalász (Kom. Pest - 110 Funde), Palotabozsok (Kom. Baranya - 3 Funde), Szentes-nagyhegy (Kom. Csongrád - 4 Funde), Budapest, Andor-strasse (Kom. Pest - 1 Fund), Vörs (Kom. Somogy - 1 Fund)..."

23 ZOFFMANN 1992.
A diadém viselőjét a szakirodalomban különböző kutatók fönöknek, sámánnak, férfinak vagy újabban nőnek határozták meg. ${ }^{24}$ Horváth Tünde kérésére ugyanis ${ }^{25}$ Mende megnézte a diadémmal megmentett és a keszthelyi Balatoni Múzeum kiállításán látható koponyát, ennek során női jegyeket fedezett fel. ${ }^{26}$

Mindezek után szerettem volna tudni, hogy modern módszerekkel férfinak vagy nőnek lehet-e meghatározni az egykoron eltemetett kiemelkedő státuszú személyt. A koponya Keszthelyen van az állandó kiállításon. Érdeklődésemre, hogy hol lehet a csontváz többi része, a Magyar Természettudományi Múzeum Embertani Tárából Pap Ildikótól azt a választ kaptam, hogy a Tárban nincs. ${ }^{27} \mathrm{~A}$ keszthelyi Balatoni Múzeumban dolgozó régészek (Müller Róbert, Horváth László, M. Virág Zsuzsanna és P. Barna Judit), továbbá Honti Szilvia, a kaposvári Rippl Rónai Múzeum régésze sem tud semmit a fej nélküli csontváz hollétéről. ${ }^{28}$ Köhler Kitti és Mende Balázs antropológusok sem tudtak embertani feldolgozásról, publikált eredményröl. A Balatoni Múzeumból kikölcsönzött koponyáról az újabb

24 BONDÁR 2015a, 112.

25 HORVÁTH 2006, 109; HORVÁTH 2008, 183.

26 Mende Balázs szíves szóbeli kiegészítését ezúton is köszönöm.

27 Ezúton is köszönöm a segítségét.

28 Ezúton is köszönöm valamennyi kolléga segítségét, levelét, szíves szóbeli közlését. 
fizikai antropológiai vizsgálatot Köhler Kitti végezte el. ${ }^{29}$ A koponya adultus korú 20-30 éves egyéné, akinek a föbb méretei - ahogyan azt már Mende Balázs korábban is megállapította - női jelleget mutatnak. A hosszú csontok hiányában a fizikai antropológia nem tud ennél pontosabb választ adni a biológiai nem kérdésére. A koponyából Köhler Kitti és Mende Balázs antropológusok (MTA BTK Régészeti Intézet) vettek mintát DNS elemzéshez. A jelenleg az MTA BTK Régészeti Intézetében végzett genetikai projekt biokémiai módszerekkel - eredményes analízis esetén - eldöntheti a kérdést: férfi vagy nő viselte a fejdíszt.

\section{Milyen fémböl készült a diadém?}

A vörsi fejdíszt említik réz, vörösréz vagy bronztárgyként, kalapált és öntött technikáról írnak a szakirodalomban. Arról, hogy bármilyen elemanalízis készült volna a tárgyról, csak kevesen tudtak. A különleges réztárgy metallurgiai analízisét a '70-es években végezték el. 1974-ben jelent meg a SAM (Studien zu den Anfängen der Metallurgie) adatbázisnak a rézkorral foglalkozó kötete, benne a vörsi diadém vizsgálati eredményével. ${ }^{30}$ Arról nincs adatunk, hogy a SAM adatfelvétele a diadém mely részéből készült. ${ }^{31}$

A vörsi diadém elemösszetétele (SAM 13738. tétel):

\begin{tabular}{|l|l|}
\hline Elemek & Koncentráció \\
\hline Réz & $? ?$ \\
\hline Ón & 0 \\
\hline Ólom & 0 \\
\hline Arzén & nyomokban \\
\hline Antimon & nyomokban \\
\hline Ezüst & $0,01 \%$ \\
\hline Nikkel & 0 \\
\hline Bizmut & 0 \\
\hline Arany & 0 \\
\hline Cink & 0 \\
\hline Kobalt & 0 \\
\hline Vas & 0 \\
\hline
\end{tabular}

Az összetevők között csak nyomokban található arzén, antimon, az ezüst $0,01 \%$, a többi mért elem nulla. A réz mennyisége nem szerepel az összetételt közreadó egyetlen sorban, de az összetevőkből nyilvánvaló, hogy majdnem $100 \%$-ot tett ki.
Rüdiger Krause 2003-ban megjelent nagy munkájában a stuttgarti Adatbank adatbázisában a SAM azonosítószámmal (13738) közli a vörsi diadém részletesebb elemzését:

\begin{tabular}{|l|l|}
\hline Elemek & Koncentráció \\
\hline $\mathrm{Cu}$ (réz) & $? ?$ \\
\hline $\mathrm{Sn}$ (ón) & 0 \\
\hline $\mathrm{Sb}$ (ólom) & 0 \\
\hline $\mathrm{As}$ (arzén) & 0 \\
\hline $\mathrm{Sb}$ (antimon) & 0 \\
\hline $\mathrm{Ag}$ (ezüst) & 0,01 \\
\hline $\mathrm{Ni}$ (nikkel) & 0,001 \\
\hline $\mathrm{Bi}$ (bizmut) & 0 \\
\hline $\mathrm{Au}$ (arany) & 0 \\
\hline $\mathrm{Zn}$ (cink) & 0 \\
\hline $\mathrm{Co}$ (kobalt) & 0 \\
\hline $\mathrm{Fe}$ (vas) & 0 \\
\hline
\end{tabular}

Az alkotóelemek között 0,001 \% nikkel, 0,01\% ezüst van, rézre itt sem szerepel adat. ${ }^{32}$

A SAM publikáció és a Krause által közzétett eredmények eltérőek, ennek oka nem világos. ${ }^{33} \mathrm{~A}$ vörsi diadém fémvizsgálatának eredménye nem gyökeresedett meg a szakirodalomban és a vizsgálat részletei, módszerei sem igazán ismertek.

A jelenleg elérhető analitikai lehetőségekkel új, roncsolás mentes metallurgiai elemzéseket végezhettünk a diadémon 2014-ben.

A Budapesti Műszaki és Gazdaságtudományi Egyetem Vegyészmérnöki és Biomérnöki Karának Kémiai és Környezeti Folyamatmérnöki Tanszékének Nukleáris Spektroszkópiai Laboratóriumában végzett energia-diszperzív röntgen-fluoreszcenciás (ED-XRF) vizsgálat ${ }^{34}$ egyértelmüen kimutatta, hogy a diadém csaknem színtiszta vörösréz (99,24 \%-a réz). Az öszszetevők között arzén nem szerepel. A szennyezőanyagok ( $p l$. cirkónium, Zr) jelenléte a földben elszenvedett folyamatokkal függ össze. Az elemzés annál részletesebb, minél hosszabb idő áll rendelkezésre a tárgy vizsgálatára. A vizsgálati módszer hibahatára ppm (parts per million) nyomelemben \pm 10 relatív százalék, \%-os mértékegységben $\pm 2 \%$. A vörsi diadém esetében a gyorsvizsgálat néhány percig, a részletes elemzés 2 napig tartott. köztudatba, a fém mintavételről csak M. Virágnak volt tudomása. A vizsgálati eredményre Kiss Viktória hívta fel a figyelmem, ezúton is köszönöm a segítségét.

32 KRAuse $2003 \mathrm{Nr} 13738$

33 A fémvizsgálatokat végző laboratóriumok eredményeinek összehasonlítását és a korszak egyéb réztárgyainak vizsgálati adatainak összevetését egy másik tanulmányban kívánom bemutatni, ezzel itt most nem foglalkozom.

34 A módszerről ld. LUTZ-PERNICKA 1996. 
Gresits Iván összefoglalása a diadémban található elemekről:

\begin{tabular}{|l|l|}
\hline Elemek & Koncentráció \\
\hline $\mathrm{Cu}$ (réz) & $99,24 \pm 0,2 \%$ \\
\hline $\mathrm{Ca}$ (kalcium) & $0,224 \pm 0,05 \%$ \\
\hline $\mathrm{Pb}$ (ólom) & $0,19 \pm 0,02 \%$ \\
\hline $\mathrm{K}$ (kálium) & $0,172 \pm 0,009 \%$ \\
\hline $\mathrm{Fe}$ (vas) & $0,0789 \pm 0,008 \%$ \\
\hline $\mathrm{Ag}$ (ezüst) & $0,0344 \pm 0,0002 \%$ \\
\hline $\mathrm{Zr}$ (cirkónium) & $0,0162 \pm 0,0002 \%$ \\
\hline $\mathrm{Ti}$ (titán) & $0,015 \pm 0,0008 \%$ \\
\hline $\mathrm{Mn}$ (mangán) & $0,0144 \pm 0,0008 \%$ \\
\hline $\mathrm{Cr}$ (króm) & $0,001 \pm 0,0009 \%$ \\
\hline
\end{tabular}

Az elemzési adatok tanulmányozásából feltünik, hogy a diadém gyakorlatilag réz, mellette más ötvöző elem csak alacsony koncentrációban fordul elö. Az eredményeket közöltük. ${ }^{35}$

Ugyancsak roncsolás mentes módszer a neutron radiográfia (NR) és prompt-gamma aktivációs analízis (PGAA), valamint a repülési idő-neutron diffrakció (TOF-ND). Ezeket a Budapesti Kutatóreaktornál a Budapesti Neutron Centrum (BNC) archeometriai kutatásokban résztvevő laborjaival (MTA Energiatudományi Kutatóközpont Nukleáris Analitikai és Radiográfiai Laboratórium, MTA Wigner Fizikai Kutatóközpont SzFI Neutronspektroszkópiai Osztály) létrejött együttmüködés során végezhettük el. ${ }^{36}$ Ezek a vizsgálatok is megerősítették, hogy a diadém nyersanyaga csaknem színtiszta réz. ${ }^{37}$

$A z$, amit a köznyelv réznek nevez valójában vörösréz (copper). Létezik még a sárgaréz (brasse) és van a termésréz (native copper), amely több helyen, a felszínen előforduló rögökben található, külső kérgén szennyezőanyagokkal, pl. arzénnel. Ezeknek a rögöknek az összetétele bizonyos elemekben eltérő lehet. A legtisztább a vörösrézből készült tárgy, ebben minimális szennyezőanyag fedezhető fel, amely a talajban lejátszódó kémiai folyamatok eredményeként kerülhetett az alapanyagra. Ilyen az arzén mellett az ezüst is kis százalékban, így ezek valószínủleg nem tudatos ötvöző anyagok, hanem természetes előfordulások a réztárgyakon, amelyek olvasztásnál még benne maradnak az anyagban. Számolnunk kell a korrózió okozta szennyeződésekkel is.

35 GRESITS 2015

36 A vizsgálatokra az EU FP7-es NMI3 projekt keretén belül került sor, a Studies on local metal production of the Carpathian Basin from the late Copper Age until the Middle Bronze Age (3500$1500 B C$ ) c. pályázat segítségével. Az együttmüködést ezúton is köszönöm Kiss Viktóriának, valamint a vizsgálatokat végzö Kasztovszky Zsoltnak, Kiss Zoltánnak, Maróti Boglárkának, Káli Györgynek és Horváth Eszternek.

37 az előzetes eredmények egy párizsi konferencián bemutatott poszteren olvashatók (KÁLI et al. 2014).

\section{Hogyan készülhetett a diadém?}

A vörsi diadém anyaga - amint ezt több vizsgálat is bizonyította - nagytisztaságú réz, amely feltehetőleg ún. másodlagos rézércek felhasználásával készült. A vörösréz rendkívül könnyen formálható, kalapálható. A továbbiakban fontos lesz majd annak megállapítása, hogy a rézrögböl hidegen kalapálták, vagy az érc megolvasztásával kinyert fémből állították elő a készítendő tárgyat.

Ennek eldöntésére első lépésként - a ma még kevés helyen hozzáférhető - sztereo mikroszkópos felvételeket készítettünk az ELTE BTK Régészettudományi Intézetében. ${ }^{38} \mathrm{~A}$ készítés technika még további aprólékos műszeres és egyéb vizsgálatokat igényel. A sztereo mikroszkópos felvételekkel megerősítést nyert, hogy a diadém szélein látható apró pontsort hátulról ütötték be, néhol a tárgy annyira elvékonyodott, hogy mai állapotában már át is lyukadt (4. ábra). A felvételek és a fémvizsgálat segítségével egyértelművé vált az is, hogy a szarvakat összefogó drót modern, a tárgy restaurálása során került a diadémra (5. ábra).

A készítés módjának rekonstruálásához igénybe vettem még a kísérleti régészet módszerét is. Ma kapható vörösréz drótból Barna Borbála ötvössel ${ }^{39}$ elkészíttettem egy, a diadémhoz hasonló, ám jóval kisebb tárgyat. Az eredmény: fakalapáccsal pillanatok alatt nyújtható, alakítható a fém. Készítés közben már nem kell hőhatásnak alávetni a rézdrótot. Érdekes adalék még a készítési technikához, hogy a drót egyik végétől indulva vékonyította lemezzé az anyagot az ötvös, amelynek végső hossza a fémhuzal „tűrőképességétől” függ. Erről a modern tárgyról is sztereo-mikroszkópos felvételek készültek az ELTE BTK Régészettudományi Intézetében a későbbi technikai összehasonlításhoz.

\section{A fejdísz analógiái}

A vörsi diadém egyedülálló lelet a késő rézkori fémművességben, így analógiája sincs. A késő rézkorból egyetlen „hasonló” darabot ismer a szakirodalom, amely Kakaslomnicon (Velká Lomnica, Szlovákia) került elő. ${ }^{40}$ Egy korábbi munkámban egy különleges edény kapcsán összegyűjtöttem a rézkori és bronzkori fejdíszeket, ${ }^{41} \mathrm{~s}$ azt tapasztaltam, hogy vannak a fej körméreténél kisebb, a szakirodalomban töredékes diadémnak vagy homlokpántnak meghatározott darabok. Az elfogadható tény ma már más értelmezést is nyerhet. Egy nemrégiben Kültepéről

38 Készült a „KMOP-4.2.1/B-10-2011-0002: Interdiszciplináris, innovatív kutatási irányok és az ipari kooperáció infrastrukturális hátterének fejlesztése valamint új oktatási technológiák bevezetése az ELTE-n" c. pályázat keretein belül, ZEISS SteREO Discovery. V8: zoom (6,3x-80x) sztereo-mikroszkóppal. A felvételeket Tóth Zsuzsanna készítette. Köszönöm Raczky Pál akkori intézet igazgatónak, hogy engedélyezte a felvételek készítését és Tóth Zsuzsannának a gondos munkát.

39 BONDÁR 2015a, 114. Ezúton is köszönöm Barna Borbála segítő együttműködését

40 Novotná 1984, Taf. 61. 362

41 BONDÁR 1998. 


\section{A KÉSŐ RÉZKORI FÉMMŰVESSÉG EMLÉKEI A KIS-BALATON TERÜLETÉN ÉS TÁGABB TÉRSÉGÉBEN}

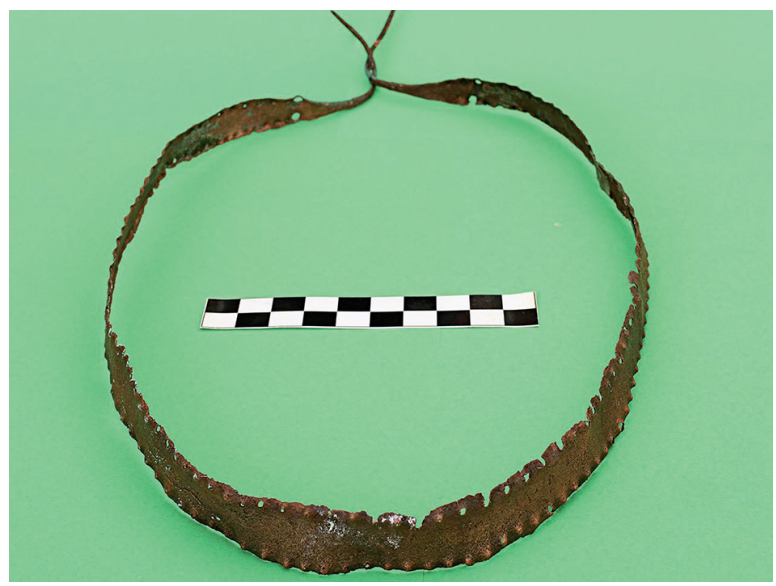

4. ábra. A vörsi diadém (fotó: Hámori Péter)

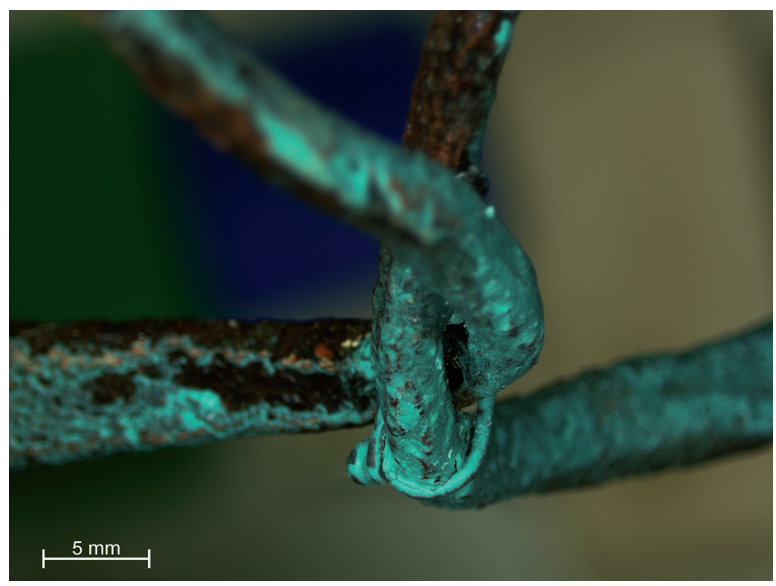

5. ábra. A vörsi diadém sztereo mikroszkópos felvétele (fotó: Tóth Zsuzsanna)

rézkés is, amely ugyanabból a gödörböl került elö, mint a tőr. Ennél többet e tárgyakról egyelöre nem tudunk megállapítani a vizsgálatok alapján.

A viszonylag kis térségben előforduló eltérő komponensű réztárgyak azonban különböző származási forrásokra (kereskedelem?), vagy nyersanyag lelőhelyekre utalhatnak. Ezt a feltételezést támasztja alá az a tény is, hogy a sármelléki telep egyazon gödrében két különböző összetételü fémtárgy került elő. Mindez kiterjedt kapcsolatokra és ismeretekre utalhat.

Korábbi munkáimban már felvetettem annak lehetőségét, hogy bizonyos területen a különleges leletek, nagyobb telepek vagy temetők és sajátos jelenségek (tömegsírok, telepgödrökbe „temetett” halottak, leölt állatok nagy száma stb.) koncentrálódása figyelhető meg, amely nem csak a kutatottság intenzitásából adódik. ${ }^{48}$ Ezek a régiók a kultuszéletben is fontos szerepet játszottak, erre utalnak a ritka kultikus leletek (idolok, kocsimodellek, kebles edények stb.) is egy-egy térségből.

$A z$ említett tényezők együttes előfordulása azt jelezheti, hogy egyes területek talán már a későbbi „városias" fejlődés előzményei lehettek: nagyobb, központi telepek körül kisebb, rövid ideig használt szatellit telepek váltották egymást, a közösségi élet, a közösségi szerveződés azonban a központi telepekhez kötődött. A mai Somogy megye területén ilyen centrum lehetett Balatonőszöd-Balatonboglár-Balatonlelle körzetében. Ezt a feltételezésemet most a fémművesség terén is megerősítve látom.
42 KüLTEPE 2010, kat. 319-321.

43 BONDÁR 2015, 7. kép

44 György L. szerint három gömbsüveg alakú rézgomb volt, az egyik szélén apró átfúrás nyoma figyelhető meg. elképzelhetőnek tartja, hogy szerves anyagra (pl. ruha) varrták fel, vagy az antropomorf urna díszítésére (mellek, szemek hangsúlyozása) használták (GYöRGY 2014, katalógus 126, 54. tábla 5-6). Itt jegyezzük meg, hogy mind a képek, mind a leltári szám alapján két rézgomb volt a 3 emeber alakú urnát tartalmazó sírban.

45 VIRÁG 1999, 40. $2 \mathrm{lj}$.

46 NAGY 2010, 439, Abb. 11. 8. A különböző vizsgálatokat végző szakemberek felsorolásánál megtudjuk, hogy a réztárgyakat Költő László vizsgálta (NAGY 2010, 6. jegyzet), a módszerröl azonban nincs információnk. Költő László roncsolásmentes vizsgálattal (röntgenemissziós, jód 124 izotóppal) analizálta a balatonlelle tárgyakat. Szíves szóbeli kiegészítését ezúton is köszönöm.

47 BONDÁR 2015b 


\section{Irodalom}

BAnNeR, J. 1956: Die Péceler Kultur. Budapest. (Archaeologica Hungarica 35)

BELÉNYESY K., HonTI Sz. és KISs V. (szerk.) 2007: Gördülő idő. Régészeti feltárások az M7-es autópálya Somogy megyei szakaszán Zamárdi és Ordacsehi között. Budapest.

BONDÁR, M. 1998: Ein kupferzeitlicher Krug aus Bátaszék. Communicationes Archaeologicae Hungariae pp. 21-31.

BONDÁR M. 2006: Kultúraváltások a rézkori emberábrázolások tükrében (Dunántúl) - Cultural changes in the ligth of human representations during the Copper Age (Transdanubia). Zalai Múzeum 15: pp. 107-124.

BondÁR, M. 2008: The Paraphernalia of Cult Life in the Late Copper Age. Acta Archaeologica Academiae Scientiarum Hungariae 59: pp. 171-181.

BONDÁR, M. 2009: Grave goods. In: The Copper Age Cemetery of Budakalász (eds Bondár, M., Raczky, P.). Budapest, pp. 245-300.

BONDÁR M. 2015: Újabb adatok a vörsi késő rézkori diadémról Recent Data on the Late Copper Age Diadem from Vörs. Magyar Régészet Online-Nyár pp. 1-6.

BondÁR, M. 2015a: The Vörs diadem: a unique relic of Late Copper Age metallurgy. Supposition, fact, new results. Antaeus 33: pp. 99-120.

BONDÁR, M. 2015b: The Archaeological Legacy of Late Copper Age communities in the Keszthely area and the Little Balaton region. In: Keszthely és környéke az öskorban - Keszthely and its Surrounding in Prehistory. Ösrégészeti kutatások KeszthelyFenékpuszta és a Kis-Balaton térségében-Prehistoric Research in Keszthely-Fenékpuszta and Little-Balaton Region. (eds Bánffy, E., P. Barna, J.). Budapest-Leipzig-Keszthely-Rahden (Castellum Pannonicum Pelsonense 7) Megjelenés alatt

BondáR M., Hontı Sz. és KIss V. 2000: A tervezett M7-es autópálya Somogy megyei szakaszának megelőző régészeti feltárása (1992-1999). Elözetes jelentés I. - The preceding archeological excavation of the planing $\mathrm{m} 7$ highway in County Somogy (19921999). Preliminary report I. Somogy Megyei Közlemények 14: pp. 91-114.

ECSEDY, I. 1977: Die Funde der spätkupferzeitlichen Boleráz-Gruppe von Lánycsók. Janus Pannonius Múzeum Évkönyve 22: 163183

ECSEDY, I. 1990: On the early development of prehistoric metallurgy in southern Transdanubia. Godišnjak 28: pp. 209-230.

ENDRőDI, A. 1997: A késő rézkori bádeni kultúra Budapest, Andor utcai telepanyaga a kulturális kapcsolatok tükrében - Die Siedlungsmaterialen der spätkupferzeitlichen Badener Kultur aus der Andorstraße im Spiegel der kulturellen Verbindingen. Budapest Régiségei 31: pp.121-175.

GRESITS, I. 2015: Non-invasive raw material analysis of the Vörs Diadem. Antaeus 33: pp. 121-122.

GYÖRGY L. 2012: A rézkori megtelepedés emlékei Kántorjánosi határában - The Relics from the Copper Age Settlement in the Vicinity of Kántorjánosi. In: Ante viam stratam. A Magyar Nemzeti Múzeum megelőző feltárásai Kántorjánosi és Pócspetri határában az M3 autópálya nyírségi nyomvonalán (szerk. Szabó Á., Masek Zs.) Budapest. pp. 81-154.

GYÖRGY, L. 2014: Észak-Kelet Magyarország a késő rézkorban A Baden kultúra leletei Borsod-Abaúj-Zemplén megyében. I-II. köt. PhD disszertáció ELTE, Budapest.

HoNTI, Sz. 1981: Rézkori temetkezés Balatonbogláron. - Ein Grab aus der Kupferzeit von Balatonboglár. Somogy Megyei Múzeumok Közleményei 4: pp. 25-38.

Hontı SZ., BelÉnyesy K., Gallina Zs., Kiss V., KulcsáR G., MARTON T., NAgy Á., Németh P. G., Oross K., SebőK K. és Somogy K. 2002: A tervezett M7-es autópálya Somogy megyei szakaszán 2000-2001-ben végzett megelőző régészeti feltárások. Előzetes jelentés II. - Rescue Excavations in 2000-2001 on the Planned Route of the M7 Motorway in Somogy County. Preliminary report II. Somogyi Múzeumok Közleményei 15: pp. 3-34.

Hontı Sz., BelÉnyesy K., Fábián Sz., Gallina Zs., Hajdú Á. D., Hansel B., HoRváth T., KISS V., Koós I., MARTON T., NÉMETH P. G., Oross K., Osztás A., Polgár P., P. Szeőke J., Serleg G., SIKLósı Zs., SófALVIA. és VIRÁGos G. 2004: A tervezett M7- es autópálya Somogy megyei szakaszának megelőző régészeti feltárása (2002-2003) Előzetes jelentés III - Preliminary Report III. The preceding archaeological excavations (2002-2003) of the M7 highway in Somogy County. Somogyi Múzeumok Közleményei 16: 3-70.

HONTI Sz., FÁBiÁn Sz., Gallina Zs., Hajdú Á. D., HoRnok P., Koós I., Mersdorf Zs., Molnár I., Németh P. G., Polgár P., P. Szeőke J., SeRlegı G., Siklósı Zs., Sipos C. és Somogyı K. 2006: Régészeti kutatások az M7-es autópálya Somogy megyei szakszán és a 67-es úton (2004-2005). Előzetes jelentés IV. Archaeological research ont he Somogy county section of the M7 highway and on Route No. 67. Preliminary report IV. Somogyi Múzeumok Közleményei 17: pp. 7-70.

HoRvÁTH T. 2006: A badeni kultúráról rendhagyó módon - About the Baden Culture - an irregular approach. Nyíregyházi Jósa András Múzeum Évkönyve 48: pp. 89-134.

HoRVÁTH, T. 2008: Socialmorphologische Studie der spätkupferzeitlichen Baden-(Pécel)- Kultur. Mitteilungen der Anthropologischen Gesellschaft 138: pp. 159-203.

KÁli, Gy., BAJNOK, K. BONdÁR, M., HORVÁTH, E., KISS, V., SiKLÓSI, Zs. \& SZILÁGYI, M. 2014: Non-destructive and Non-invasive Archaeometallurgical Investigation on Copper Age Artefacts from the Carpathian Basin. In: Synchrotron radiation and neutrons in art and archaeology (SR2A-2014) Musée du Louvre, Paris, 9-12 Sept.

KIRÁLY I. Sz. (szerk.) 2004: Az M7 autópálya Somogy megyei szakaszának megelőző Régészeti feltárásai I-II-III. Kaposvár.

KöHLER, K. 2015: Anthropological assessment of the Vörs Skull. Antaeus 33: pp. 123-126.

KöLTŐ L. és VÁNDOR L. 1996: Évezredek üzenete a láp világából. Régészeti kutatások a Kis-Balaton területén 1979-1992. Kaposvár - Zalaegerszeg.

KRAUSE, R. 2003: Studien zur kupfer- und frühbronzezeitlichen Metallurgie zwischen Karpatenbecken und Ostsee. (Vorgeschichtliche Forschungen 24).

KüLTEPE 2010: (Kulakoğlu, F., Kangal, S., eds): Anadolu'nun Önsözü, Kültepe-Kaniş Karumu Asurlular Istambul'da. Bu katalog. Aya Sofya, Aya Irini Müzesi'nde 29 Arahk 2010 - 28 Mart 2011. Kayseri Büyükşehir Belediyesi Kültür Yayinlan 78. Istambul.

LIGNER J. 2010: Szebény határa (Baranya m.) RKM p. 353

LUTZ, J., PERnicka, E. 1996: Energy dispersive X-ray analysis of ancient copper alloys: empirical values for precision and accuracy. Archaeometry 38: pp. 313-323.

MoLNÁR I., Sípos C. 2005: Balatonlelle-Rádpuszta, Romtemplom mellett (Somogy m.) RKM pp. 180-181.

MoLNÁR I., Sípos C. 2006: Balatonlelle-Rádpuszta, Romtemplom mellett (67/5 lelöhely). In: HoNTI et al. 2006, pp. 51-56.

NAGY, B. 2010: Gräberfeld der Badener Kultur in Balatonlelle-Felső Gamász. Antaeus 31-32: pp. 375-498.

NÉMETH P. 2009: Lengyeltóti, Rice-puszta (KÖH 69879). RKM p. 261. NeMESKÉRI, J. 1956: Anthropologische Übersicht des Volkes der Péceler Kultur. In: BANNER 1956, 295-311.

NovotNÁ, M. 1984: Halsringe und Diademe in der Slowakei. (Prähistorische Bronze Funde XI. 4)

PEKÁRY, T. 1954: Vörs. Archaeologiai Értesítő 81: p. 72.

RKM: Régészeti Kutatások Magyarországon - Archaeological Investigations in Hungary. (szerk. Kisfaludi, J.) Kulturális Örökségvédelmi Hivatal és Magyar Nemzeti Múzeum. Budapest.

SAM 1974: Studien zu den Anfängen der Metallurgie (hrsg. Bittel, K., Junghans, S., Otto, H., Sangmeister, E., Schröder, M.) Berlin Bd. 2. Teil 4

Terei Gy., Horváth L. A., Korom A. és SzILAs G. 2004: Budapest, XI. Köérberek, Tóváros lakópark. RKM pp. 196-197.

VIRÁG M. Zs., 1999: A badeni kultúra rézleletei Sármellék-Égenföldről. Die Kupferfunde der Badener Kultur in Sármellék-Égenföld. Zalai Múzeum 9: pp. 33-54.

ZofFMANN Zs. 1992: Kelet Kárpát-medence és rézkori népességeinek embertani vázlata. Kandidátusi értekezés. Kézirat. Budapest. 